\title{
Agradweep Carnival (Mela) and Baruni Festival A Part Of Glorius Secreat Geography in India
}

\author{
${ }^{1}$ Biplab Das, ${ }^{2}$ Utpal Khara \\ ${ }^{1}$ Research Scholar $(P h D)$ Indian Institute of Engineering, Science and Technology, Kolkata \\ ${ }^{2}$ Research Scholar(PhD) University of Calcutta
}

\begin{abstract}
Religious places are one of the important tourist resources. Religious places are related to all religions have a tourist significant, only the degree of important varies from place to place. One of them is Gopinath Temple which is Hindu (baisnab) religion related. It is quite old and attract a large number of tourist through it has location of disadvantages, find hopefully this tourist resources will have a great tourist significant in the days to come. In this background this religious spot is chosen for the study. This historical place is located on Agradweep village of Katwa sub-division of Bardhaman district.
\end{abstract}

\section{Objectives Of The Study:}

1. To gain the information on Gopinath Thakur, significant person of ancient Baisnab history and local people's respect and faithful on him.

2. To earn the knowledge in erosion of Bhagirati river and destruction of Gopinath Mandir.

3. To estimate the information of economic loss on local peoples due to Bhagirati river erosion and people's belive on Gopinath Thakur.

4. To develop the tourist spot as Agradweep area to highlight the natural beuty and historical religious significant of the location.

\section{Methodology:}

In the study of Gopinath Temple two sources of information has been obtained, i.e., primary and secondary data. The primary data is obtained from held survey by collecting the answers of extensive questions which includes all aspects of socioeconomic condition like age, sex, occupation, education level, income of correspondent. The primary data also collected from the temple authority, prist and person of the villages. Though my study is based mainly on primary data but I also collected secondary data from mahakuma library, Katwa information centre, NATMO, Gazetteer, different books etc. just to get a general idea about the background of the study area and its tourism potentiality.

The dissertion is manly descriptive one, but the discussion and analysis is base: $\mathrm{d}$ on field survey as well as secondary data. In this context, I have adopted both statistical analysis and cartographic representation based on survey data. I have computed and used different statistically techniques. Primary date was collected from the fild in the form of temple survey, tourist survey etc.

The research work prepared in three stages which are as follows -

Pre-field work:

This stage includes -

i) collection of districts map.

ii) collection of secondary information from district handbook, cesus report, others books and journals etc.

iii) preparation of questionnaire statistical schedule for collection of primary data which are closely related with the research work.

Field work:

By questionnaire schedule primary data will be collected from the study area. Observation schedule also help to collect the information.

Post field work:

Collected data will be classified in a master table and various cartographic and statistical techniques will be made in support of the theoretical discussion. 


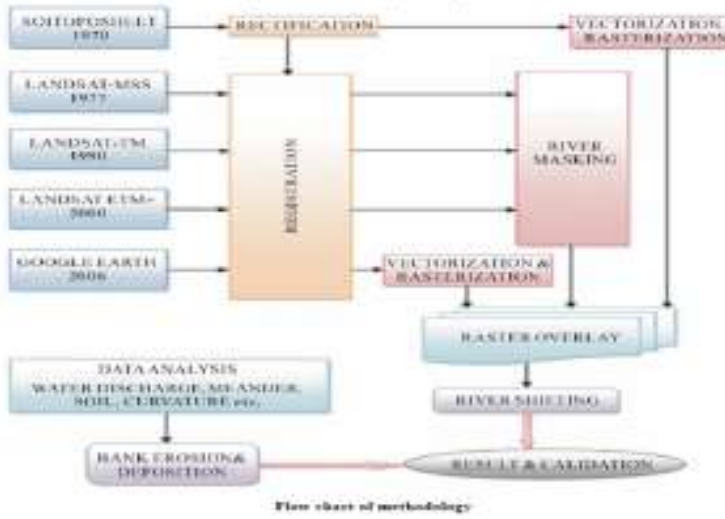

Fig-1: Flow Chart of Methodology

\section{Significance Of The Study:}

Every carnival or festival is important in particular society. Baruni festival is same important in Baisnab society at agradweep. Moreover every religious places are related to all religions have a tourist significant, only the degree of important varies from place to place. One of them is Gopinath Temple which is Hindu (baisnab) religion related. It is quite old and attract a large number of tourist through it has location of disadvantages, find hopefully this tourist resources will have a great tourist significant in the days to come. In this background this religious spot is chosen for the study. This historical place is located on Agradweep village of Katwa subdivision of Bardhaman district.

FAIR SHOP:

\section{Results:}

Demographic Condition:

Age and Sex :

Around $27 \%$ of the fair shopkeeper are under the age of 30 years and $41-50$ years. Between $31-45$ age group $18 \%$ and above 61 years $18 \%$ people lie. Shopkeepers are mainly male. Only $18 \%$ shopkeepers are woman.
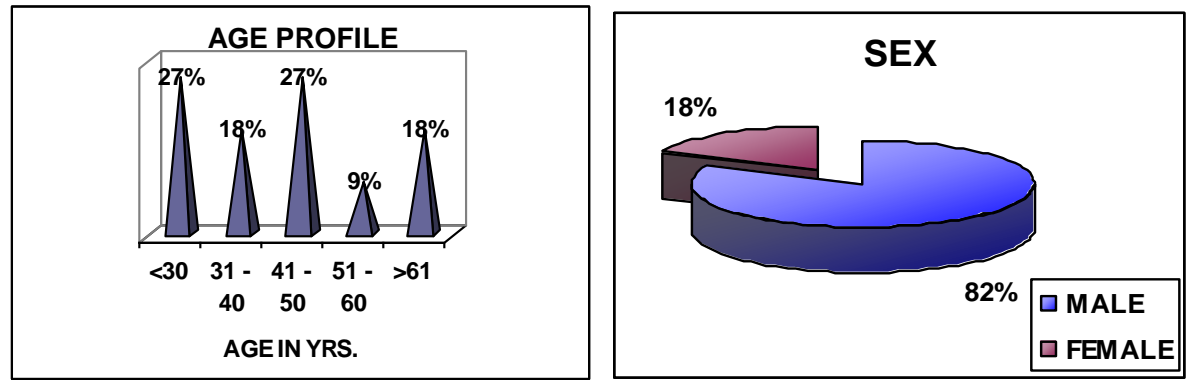

Fig-2: Age-Sex condition of shopkeeper in carnival

Social Condition:

Religion and Castes:

$18 \%$ of the shopkeepers are Muslim and $82 \%$ belong to Hindu religion. Among the hindus shopkeerers, $72 \%$ are of General Castes and $10 \%$ belongs to scheduled castes.

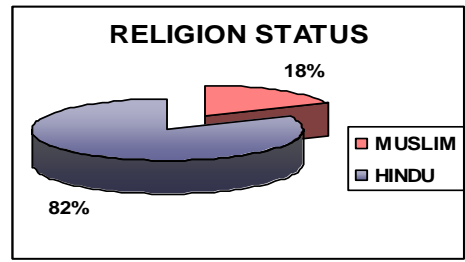

Fig-3: Religion Status

Family:

About $72 \%$ of shop keepers have families with 2 or less male members and $64 \%$ have families with 2 or less female members. But there are about 36\% families with 2-4 female members. But no family consists of more than 4 male or female members. 

Education:

$36 \%$ of shopkeepers are under - Madhyamik but $9 \%$ are graduation. $27 \%$ of the shopkeepers are below primary standards. About $9 \%$ shopkeepers of higher secondary qualified.

Marital Stutus:

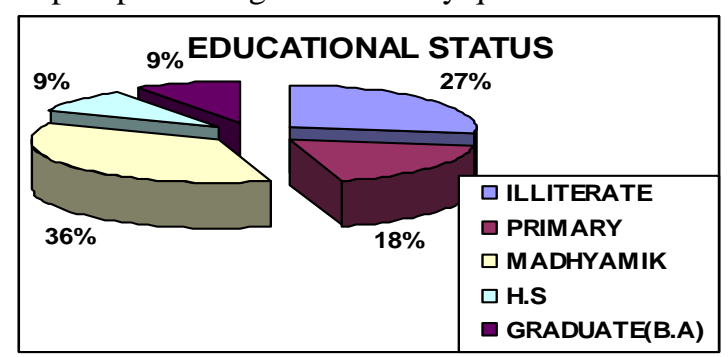

Fig-4: Educational Status of shop-keepers

About $73 \%$ of the shop keepers are married and $27 \%$ of shopkeepers are unmarried. This implies that most of the shopkeepers are adults.

Economical Condition:

Occupation:

$40 \%$ of the shopkeepers are dependent on their shops for income. But $30 \%$ of the shopkeepers are also in agricultural works. They set up shops only during festivals and fairs and other time

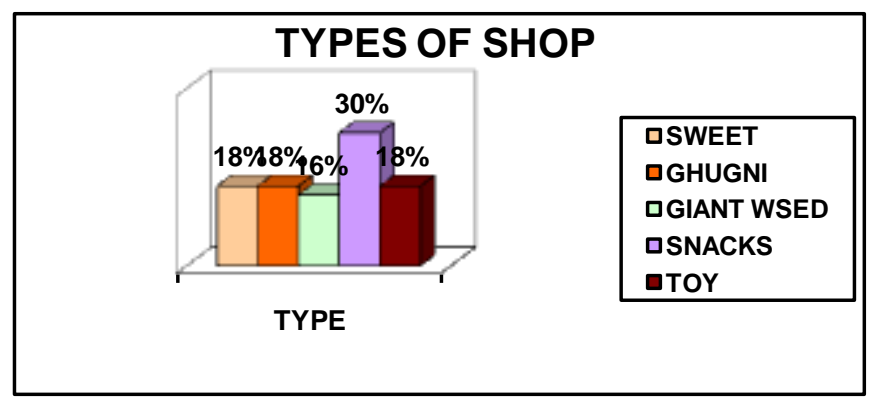

Fig-5: Types of shop

they work in agricultural field. $10 \%$ of female shop owners are housewives. About $20 \%$ of shopkeepers work in agricultural fields or any other field as labors.

Daily Sale and Income:

During the fairs, among the shopkeepers, about $27 \%$ have daily sale less than Rs.500, but $45 \%$ of shopkeepers have daily sale in between Rs. $501-1300.9 \%$ of shop keepers have more than Rs. 2100 sale. $18 \%$ have sale in between Rs.1301 - 2100. : 64\% of the shop keepers have an income of Rs. 150per day. 9\% have a daily income of Rs. 450 and $27 \%$ shopkeepers have a sale in between Rs. 150-450.
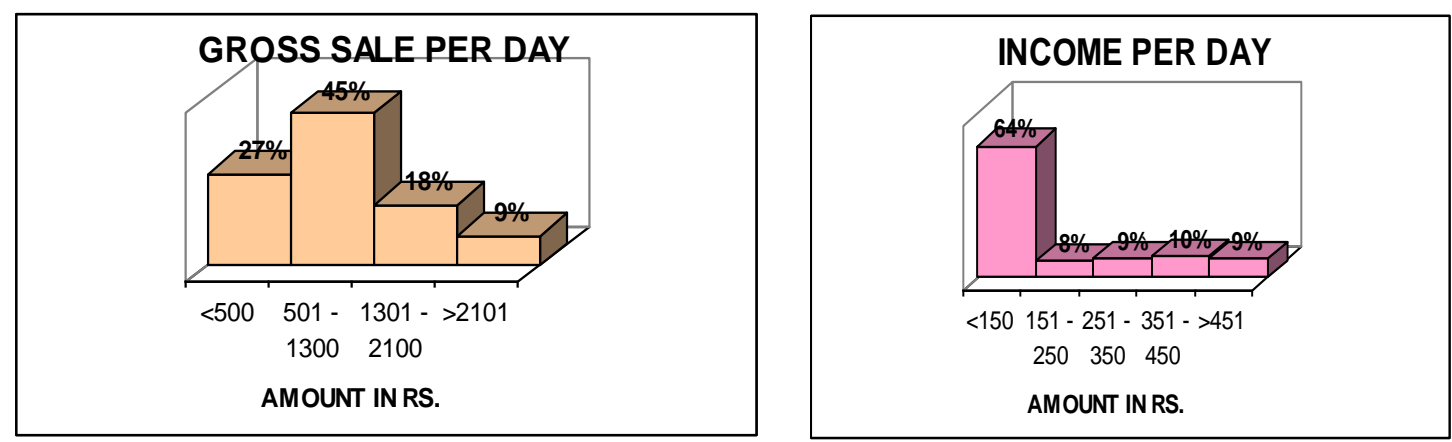

Fig-6: Daily Sale and Income

BAWL SINGER IN CARNIVAL:

Demographic Condition:

Age and Sex Structure: 
In Agradweep, about $42 \%$ of the banks are in between the age group of $50-60$ years only $14 \%$ of the Bawls are above the age of 60 years. 28\% of Bawls of in between the age group of 40-50 years and only $14 \%$ are below the age of 40 years.
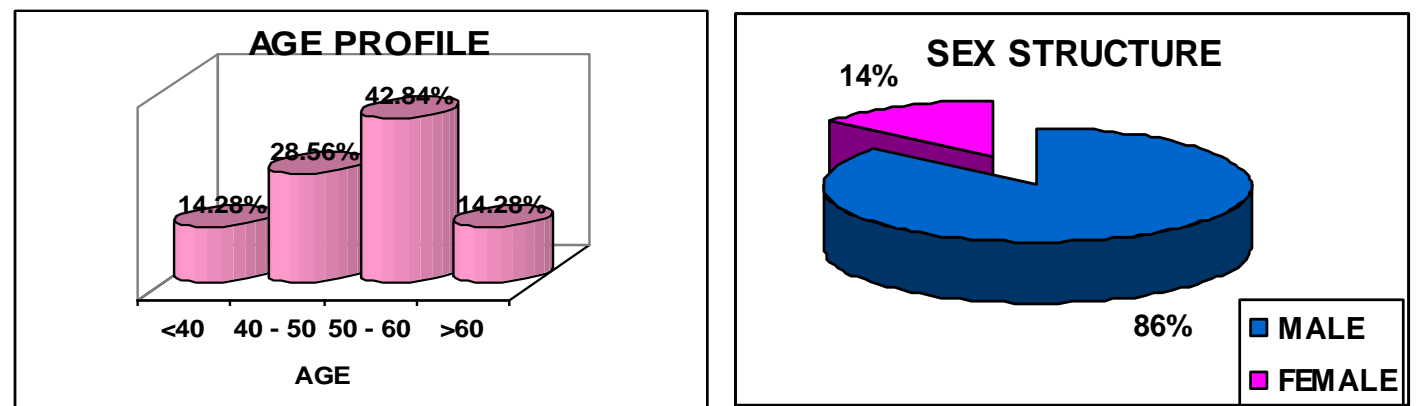

Social Condition:

Fig-7: Age-Sex Structure of Bawl Singers

Religion and Caste:

All of the Bawls are Hindu. About $57 \%$ of them belong to general caste and $43 \%$ of them belong to scheduled castes. But there is no issue of caste among the Bawls.

Family Member:

Out of Bawls coming to Agradweep, about 14\% have family's nature the number of male members are 2 or less and $28 \%$ have female members 2 or less then $2.80 \%$ Bawls have $3-4$ male members in their family while $57 \%$ have 3-4 male members in their family while $42 \%$ have $3-4$ female numbers in family. About $28 \%$ have more than 4 male members in their family and other $28 \%$ also have more than 4 female members in the family.

Education:

About $23 \%$ of the Bawl population is illiterate. About $26 \%$ of Bawls have qualified higher secondary examination. 25\% of the Bawls are under Madhyamik standareds. $26 \%$ of the Bawl have qualification above higher secondary. So it can be concluded that though $23 \%$ of the Bawls are illiterate but majority (77\%) of the Bawl population are educated.

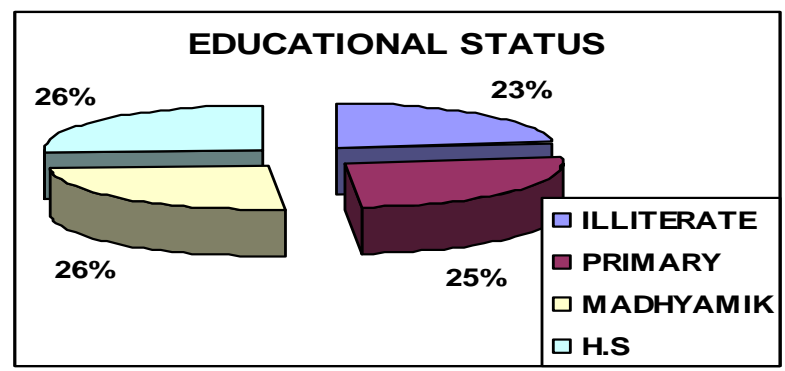

Marital Status:

Fig-8: Educational Status of Bawl Singer

Only $57 \%$ of the Bawls are married and $43 \%$ are unmarried. That means a section of the Bawl community is unmarried.

\section{Economic Condition:}

Occupation:

About $43 \%$ of the Bawl do not have any other profession. About $29 \%$ of the Bawls are engaged in agriculture work. $14 \%$ of the Bawl population has fishing as occupation. About $14 \%$ work as labours. So it can be concluded that about $57 \%$ of Bawl population are engaged in one or another occupation. 

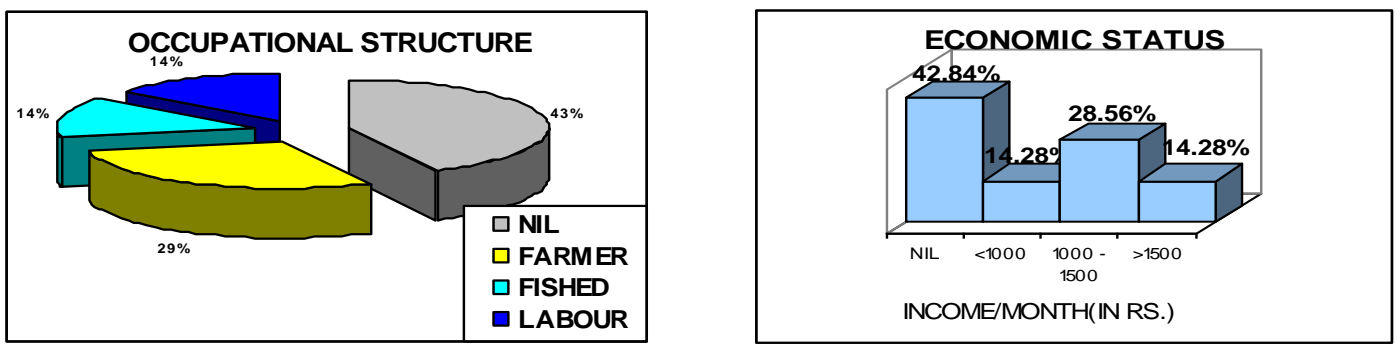

Fig-9: Occupational Structure and Income of Bawl Singers

Monthly Income:

About $43 \%$ of the Bawl community does not have any significant monthly income. $14 \%$ of the Bawl population has monthly income below Rs. 1000. 28\% has income between Rs.1000 - 1500 and $14 \%$ has income more than Rs. 1500.

Other information:

Most of the bawl nearly $42 \%$ come here from cover a distance of less than $50 \mathrm{Km}, 28 \%$ cover $50-100$ $\mathrm{Km}$. distance, except this more than $100 \mathrm{~km}$ is covered by only few bawl. Bawls' have to make their own food. Only $29 \%$ are able to get food from village houses and $14 \%$ survive getting food from relatives. At the time of fair, about $42 \%$ bauls get accommodation facility by known people, $20 \%$ place is arranged by fair committee. $20 \%$ stay on river bank and others on river bank.

\section{TOURISTS OF THE FAIR:}

\section{Demography Condition}

Age: $25 \%$ of the tourists are below the age of 25 years but about $12 \%$ are in between the age of 26-45 years $12 \%$ of the tourists are above the age of 56 years. $37 \%$ of the tourists are in between the age of $46-55$ years. This proves that people of all age groups deliberate by come to Agradweep fair.

Sex: About $18 \%$ of the tourists coming to Agradweep fair are women. The main reason for the low percentage of women tourist to Agradweep fair that the major portion of women is of local population. Again it is very difficult for women of far places to visit Agradweep for fair because of many reasons. The most number of tourists $(82 \%)$ therefore are men.
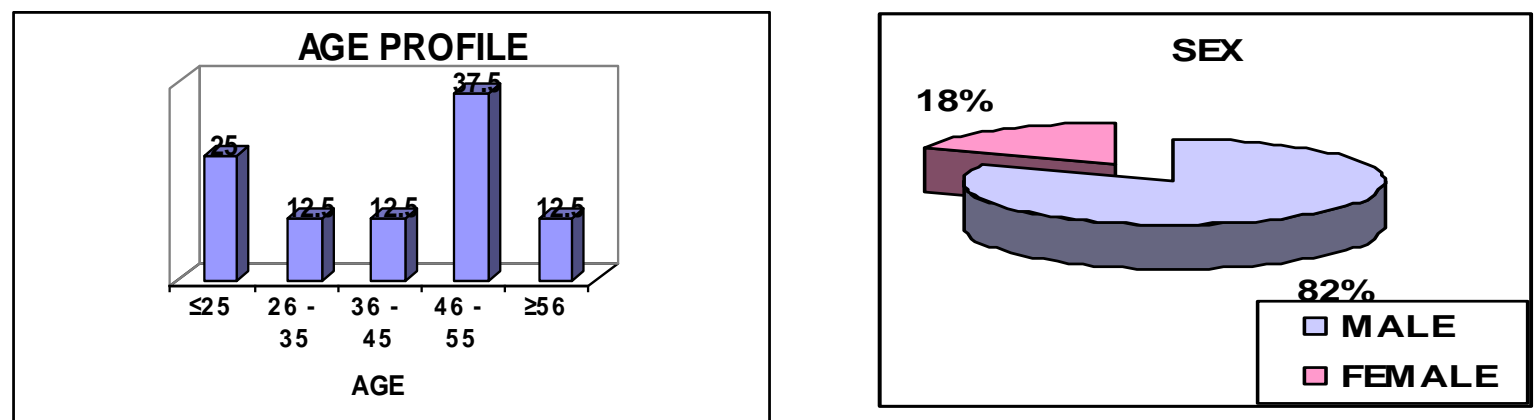

Fig-10: Age-Sex Structure of Tourists of the Fair

Social condition:

Religion: About 49\% of all tourists are Hindu, 25\% are Muslim, 13\% are Buddhist and rest 13\% are Buddhists. So, it is evident that people from all religions visit the fair.

Education: About 24\% of the tourists are illiterate. But around 25\% are under Madhyamik, 26\% have qualified higher secondary and graduation. Also about $25 \%$ are Master's degree holders. 

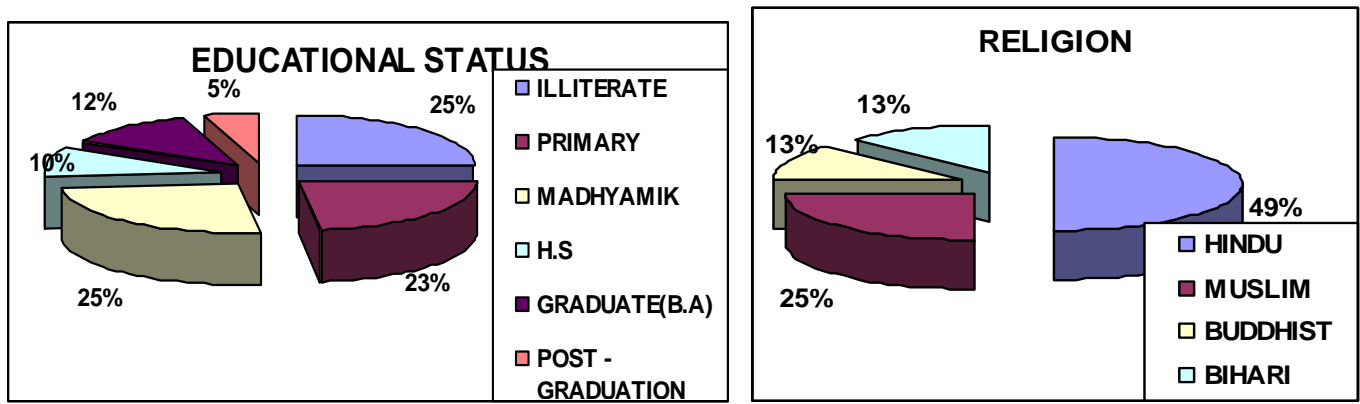

Marital Status:

Fig-11: Religion and Education Status of Tourists of the Fair

About $58 \%$ of the tourists are married and the rest $42 \%$ are unmarried. So, it is seen that both married and unmarred people.

Economic Conditions:

Occupation: $25 \%$ of the tourists are unemployed. Another $38 \%$ of the tourists work as daily wage labours. About $25 \%$ of the tourists are students and rest $12 \%$ of the tourists are engaged in fishing and pottery to earn their livelihood.
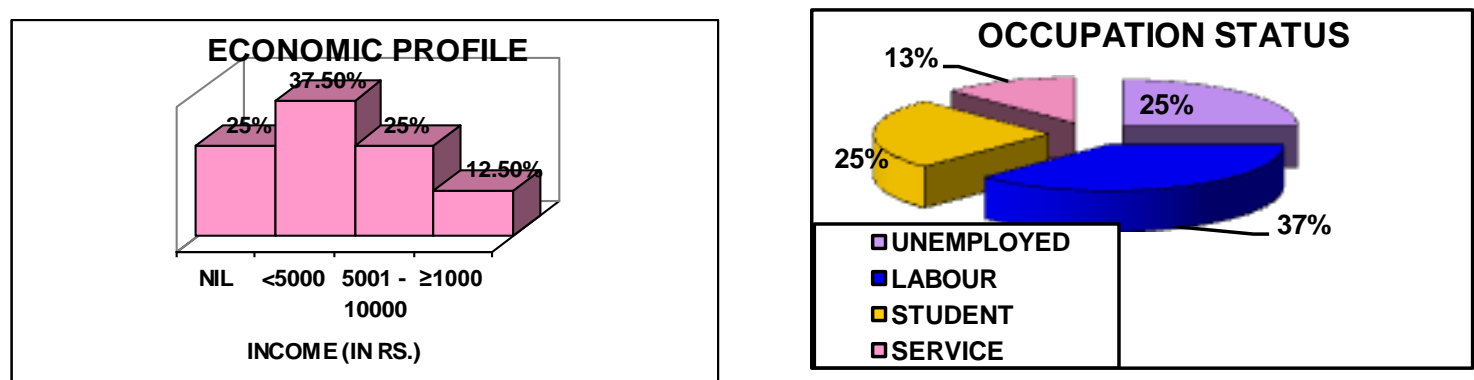

Monthly Income:

Fig-12: Economic Profile and Occupation Status of Tourists of the Fair

About $25 \%$ of the tourists do not have any significant monthly income. $37 \%$ of the tourists earn Rs. 5000 or less per month. $25 \%$ of the tourists have monthly income in between Rs. 5000 - Rs. 10000 . Only $12 \%$ of the tourists earn more then Rs. 10000 per monthly.

Other information:

Almost 50\% tourist come from in between $40 \mathrm{Km}$ distance, $24 \%$ are from $40-80 \mathrm{Km}$, greater t6han $80 \mathrm{Km}$ merely come.

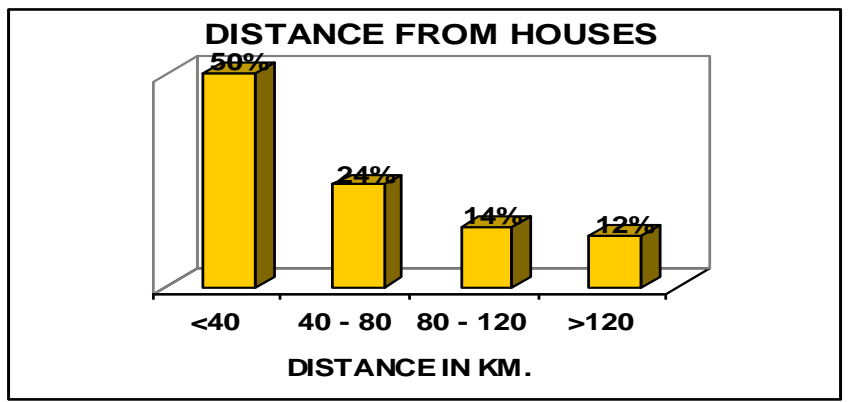

Fig-13: Distance from House to Carnival of Tourists of the Fair

Most of the visitors about 37\% stay in their relative house for 2-3 days for fair purpose. $25 \%$ go back to their home. $12 \%$ only stay for $4-5$ days. $25 \%$ of the tourists stay on river bank. 

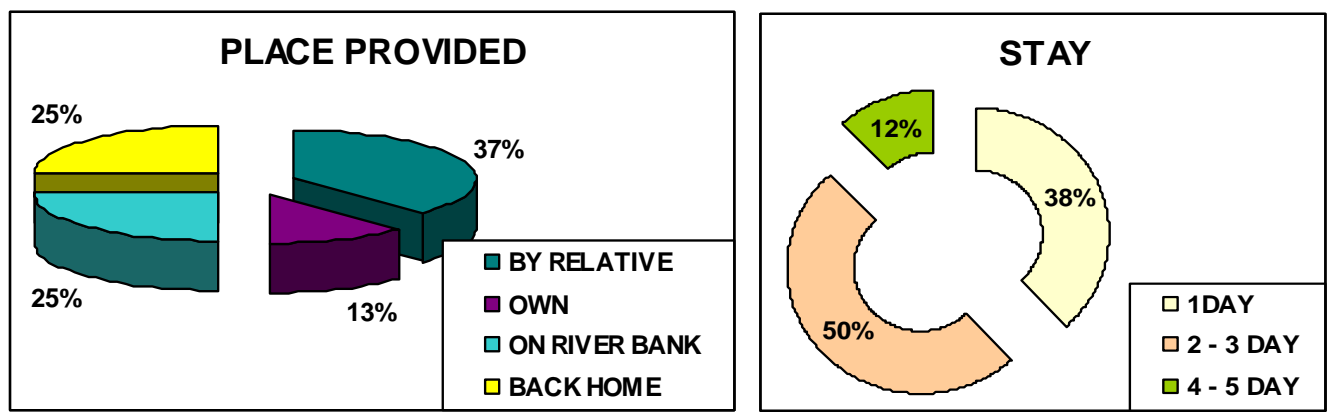

Fig-14: Stay Condition of Tourists of the Fair

\section{Conclusion:}

Even the pride of the hundred year old is huge and about one lakh of people comes to Agradweep for bathing in the Ganges during Baroni, there remains a pyramid of ill management of the preparations for food shelter issue of the pilgrims. Many pilgrims, after worshipping in the temple returns to the nearby town Katwa for staying. This a set back for Agradweep to be an attractive tourist-stop.Due to unruly nature of the most of pilgrims, ignorance of the people of Agradweep and inactive role of the administration and Panchayat Samiti, the pollution free banks of Agradweep becomes a hub of pollution every year during the festival.All last can said that the erosion of the banks of the river Bhagirathi was able to suppress the sense of devotion of the people of Agradweep and the pilgrims but increased it exponentially. During this period, the whole of Agradweep in the mood of Celebrations and enjoyments.

\section{References:}

[1] Radhakamal mukherjee, The Changing Face of Bengal (Calcutta: University of Calcutta, 1938), p. 141

[2] W.S. Sherwill, Report on the rivers of Bengal, (Calcutta: Calcutta printing and publishing Company, 1858), p. 17.

[3] James Rennell writes, "The Cossimbazar river is almost dry from October to may" (Memboir of a Map of Hindoostan (London, 1788), p. 385.

[4] Annual Report on Major rivers, 1931-32, Nadia River Division, p. 12, quoted in Kalyan Rudra, ibid.

[5] Das.B and Bandyopadhyay.A.(2012). 'Causes of Flood by Indian River' A Case Study of

[6] Transboundary River Icchamati in Gangetic Delta, International Journal of Advanced Research in Computer Science and Electronics Engineering,Volume 1, Issue 7, September 2012,277-292, ISSN: 2277 - 9043.

[7] Das.B(2011).Flood Risk Management by Transboundary River of Gangetic Delta ,Lap Lambert Academic Publishing ,Saarbrücken, Germany,65-79.

[8] Giri.P, Barua.P and Das.B(2012).'Sundarban Delta: Perspective for the Long Term Future', Lap Lambert Academic Publishing ,Saarbrücken, Germany,84-143.

[9] Jadunath Sarkar writes, "time has leveled to the dust the glories of the Gauda under hindu and Muslim rule and the ruins of their capital lies scattered in heaps for miles along the eastern bank of Kalindri river through which flowed the main current of the Ganges down to the close of the thirteenth Century" 9the History of Bengal: Muslim period 1200-1757, [Patna: Academia Asiatica, 1973], p. 24)

[10] W.S. Sherwill, Report on the rivers of Bengal, (Calcutta: Calcutta printing and publishing Company, 1858), p. 17 